\title{
Development of a Model for Organizing Cultural Activities to Study Buddhist Teachings at Temples in Bangkok, Thailand
}

\author{
Phrakhru Pariyattithammakhun Piwsa ${ }^{1}$, Kla Somtrakool ${ }^{1} \&$ Anchalee Jantapo $^{1}$ \\ ${ }^{1}$ The Faculty of Cultural Science, Mahasarakham University, Khamriang Sub-District, Kantarawichai District, \\ Maha Sarakham, Thailand \\ Correspondence: Phrakhru Pariyattithammakhun Piwsa, 119 Ram 1 Road, Rong Muang, Pathumwan, Bangkok \\ 10330, Thailand. E-mail: pariyattithom@gmail.com
}

Received: March 29, 2013 Accepted: May 18, 2013 Online Published: June 28, 2013

doi:10.5539/ass.v9n9p64

URL: http://dx.doi.org/10.5539/ass.v9n9p64

\begin{abstract}
Buddhism is an intrinsic feature of Thai culture. With a ninety percent Buddhist population, Thailand has been built around the principles of Dharma. These principles have traditionally been taught to the local community by temples, through a variety of different activities. Recently, however, Thai society has adopted an increasing number of Western cultural features that have caused the importance of traditional Buddhist activities to decline. This research tries to understand the reasons for the decline of community interest in local Buddhist activities in Bangkok, so to propose a model for the organization of such activities and ensure that they are not lost to future generations.
\end{abstract}

Keywords: Buddhism, temple, activity, culture, society, organization, development

\section{Introduction}

Buddhism originated in India two thousand five hundred years ago at a time of many religions and doctrines. Each of these religions and doctrines had ancient foundations of belief, making it extremely difficult for Buddhism to occur. The birth of Buddhism caused all other religions and doctrines to revise and reconsider their faith, as Buddhism taught the concepts of cause and effect from the enlightenment of Samyaksambuddha, through the Buddha's five ascetic companions and his Shravaka (disciples). The central doctrine was accepted and called the 'Four Noble Truths'.

After his enlightenment, the Lord Buddha announced his teachings so that his disciples and Buddhist followers could gain access to enlightened conduct, such as in the text Dhammacakkappavattana Sutta, or 'the setting in motion of the wheel of Dharma'. This was the Lord Buddha's first sermon after his enlightenment, which was given to his five former companions and teaches his path to enlightenment. The Pratimoksa, a list of rules for Buddhist monks, is another such example. These were the origins of the transmission of Buddhism and their concrete foundation enabled people all over the world to accept the doctrines of cause and effect taught by the Lord Buddha.

Following the adoption of Buddhism by the Thai people, temples were constructed as religious centres for transmission of the faith in the communities and were also the locations of a variety of different activities, as well as being artistic and cultural centers for creation and conservation, and places for teachers to instruct. Youths had an opportunity to meet during events at the temple. They were places of settled and stable community life, where various festivals and celebrations of the local community were held. They were also places of community education, local libraries and resource centres, medical herb gardens, local massage centres and centres of worship and respect. It was the responsibility of the monks to oversee the organization of such ceremonies and events, so they had to be knowledgeable experts in both doctrine and ways to develop the community. The temples were places of trust in the community and, as representatives of the temple, so monks were figures of trust.

Thai culture is derived from the doctrines of Buddhism and there are many activities at the temples that concern culture and religion in the life of a Thai national. However, a number of characteristics of everyday lifestyle have been lost to modern society. When Thailand absorbs other cultures, people neglect virtue and morality, which has caused Thailand problems in the past regarding competition and comparison with other countries. It is for this 
reason that governmental and private institutions are trying to develop the country in ways to combat past failures. The discipline and ideals of Buddhism have been identified as media with which to aid these developments. Buddhism can help in two ways. The first is by being disciplined in observing the law or constitution and the second is by obeying clerical acts. This is primarily because Buddhists in Thailand comprise ninety percent of the population but also because Buddhism is non-confrontational by nature (Malatong, 1990, $\mathrm{p}$. 130).

Culture refers to the representation of the lifestyle of a society, including various beliefs, customs, knowledge and technologies. Culture often requires the use of natural resources. There are four clear characteristics of culture which are knowledge, social heritage, lifestyle and invention or improvement. For Thai culture, there are two types. The first is the founding culture of the nation, which must be maintained for the pride, identity and trust of future generations. The second is adopted culture from connections with other nations. There are also four sub-categories of Thai culture, which are Buddhist doctrine, legal doctrine, material doctrine and social doctrine (Pinitjan, 1994, p. 14-19).

Bangkok is the capital city of Thailand and has a special administration of fifty-four districts. There are therefore a number of different types of community throughout the city, each with different cultures, including urban communities, slums, high-rise communities, allocated communities and suburban communities. There are four-hundred and thirty-six Buddhist temples in Bangkok, in each of the various different communities. The temples and communities will collaborate to organize regular activities to strengthen their relationship and give the community members opportunity to worship. These activities help to renew the morals and virtues of the community and reduce social problems (Kosajarn, 2002, p. 17).

In the past, home, temple and school had very close relationships. The school and temple would usually be in the same area. Students would eat at the temples and clean the temples. The children were taken to listen to Buddhist preaching regularly and were also encouraged to enter the monkhood. When there were school or temple activities, the members of the local community would volunteer to help with the organization and planning of the events. Nowadays, the economy and society has changed. The children are now encouraged to work in the cities and the schools are not in such close proximity to the temples, causing the relationship between home, school and temple to weaken. As a result, the abilities of monks to deal with the community in some temples have weakened, parents no longer have the time to take their children to make merit and the majority of children entering the monkhood do so only for the minimum time period of seven to fifteen days. These all result in a number of social problems. Aside from these issues, Western culture has been imitated too much and the values of the past are disappearing because of rapid governmental development, placing emphasis on material culture (Kunaporn, 2008, p. 14).

Bangkok is the most economically, technologically and scientifically developed city in the country, with the most inhabitants. Despite this, there are many social, economical and political problems. This research will study these problems related to the organization of cultural activities at temples and address their cause in order to identify a method to solve them in line with dharmic principles by outlining a model of development for organizing cultural activities to study Buddhist moral code.

\section{Research Aims}

This research has three aims: a) to study the historical background of temples and the organization of cultural activities to study Buddhist teachings at temples in Bangkok, Thailand; b) to study the problems with and methods of organizing cultural activities to study Buddhist teachings at temples in Bangkok, Thailand; c) to develop a model for the organization of cultural activities to study Buddhist teachings at temples in Bangkok, Thailand.

\section{Research Methodology}

This is a qualitative research that was begun in August 2011 and continued for a time period of one year. The research area for this study was selected using a purposive sampling method from temples in Bangkok with three requirements. The first requirement was for the temple to have an established tradition of organized activities. The second requirement was a surrounding community of people with knowledge about the background of cultural activities held by the temples. The final requirement was an area where the culture and way of life were different from the surrounding environment. From these characteristics, four temples and their districts were selected: a) Chamnihattakan Temple, Pathum Wan District, Bangkok; b) Khlong Toei Temple, Khlong Toei District, Bangkok; c) Weluwanaram Temple, Don Mueang District, Bangkok; d) Buranawat Temple, Thawi Watthana District, Bangkok. The research population was comprised of twelve key informants and ninety-two casual informants selected by purposive sampling and one-hundred general informants selected by accidental 
random sampling. Data collection tools in this research included structured and non-structured interview, observation, focus group discussion and workshop. The non-structured interview was used with key and casual informants to obtain data regarding general information, community history, jobs, lifestyle and general requirements. The structured interview was used with key and casual informants to obtain data regarding detailed information, customs, beliefs and ceremonies in the temple, community cooperation, problems with organization of activities, activity objectives and the organization model for temple activities. General observation was conducted in the community by attending and participating in various temple activities, both regular and special events. The focus group discussion was held with key informants, casual informants and general informants in order to discuss the history, conditions, problems, responsibilities, positions, organization and requirements of the temple activities. The discussion was also used to highlight any anomalous data. The data was validated throughout the research process and preliminary steps were taken to ensure due process as follows: a) the researchers collected the data from document study and field research; b) an interview was conducted; c) advisors were asked for recommendations; d) the research tools were checked for content validity by experts; e) the researchers corrected problems with the research tools found by the experts; f) research tools were finalized for use during the research. The research employed documentary and field research methods and used a triangulation method for data verification. The results are here presented in the form of a descriptive analysis.

\section{Results}

\subsection{The Historical Background of Temples and the Organization of Cultural Activities to Study Buddhist Teachings at Temples in Bangkok, Thailand}

Chamnihattakan Temple was previously named Sam-ngam and is the oldest temple in Pathum Wan District, Bangkok. It was built at the start of the Rattanakosin era in 1824. Phraya Chamnihattakan donated his own money and land to create a large and beautiful temple in order to enhance his honor and reputation. King Mongkut, or Rama IV of Thailand, gave the temple its new and current name, Chamnihattakan Temple. The temple was given its new name in 1904 but the surrounding community retained its original name of Sam-ngam. The temple covers four rai, or one and a half acres, and the temple area seven rai, almost three acres. The prominent feature is the main hall of the temple, which used Thai and Chinese architecture. At the front of the temple, on the arches of the doors and windows are three Buddharupa, or models of the Buddha, in the positions of touching the earth (Pangmanwichai), reclining (Wihanpranon) and fearlessness. The disciples Katyayana and Sivali are also represented; this is the only representation in Thailand of Sivali sitting.

Khlong Toei Temple was constructed in Khlong Toei District in 1927. Nowadays, the temple covers almost five acres. The prominent feature of the temple is an appliance and utensils museum, showcasing the tools of the past, such as bowls, pots, vases, old tiles in Chinese and ancient Thai style and Thai porcelain, as well as horticultural displays. Other than this, the temple has a pet crematorium.

Weluwanaram Temple in Don Mueang District was built in 1901 during the reign of King Chulalongkorn, or Rama V. The temple was previously named Nong Pagog as part of the city Nonthaburi before the borders were redefined and the temple was included in Don Mueang District, Bangkok. The locals continued to colloquially refer to the temple as Nong Gog until Phra Ajarn Non changed the name to Weluwanaram Temple. The temple covers an area of three and a half acres and is notable for the beautiful walls and ceilings of its halls. The main Buddhist statue is over one hundred years old.

Buranawat Temple was given permission for construction in 1854 and has a famously holy name with supernatural power that inspires the fulfillment of the worshipper's wishes. The important feature is the sacred Buddharupa, with the name Luang Por In Luang Por Jan, who was an ancient idol of the local area.

Important cultural activities are organized by each of the temples on the Buddhist holy days of Vesak (Visakabucha), Asanha Bucha and Makha Bucha. The activities include Buddhist chanting, observance of the Buddhist precepts, Bhavana (meditation) and making merit. There are also activities held on national days, such as Father's Day (the birthday of the Thai king) and Mother's Day (the birthday of the Thai queen). Lights are fixed to decorate the area outside the temples and the image of the king or queen will be raised in front of the temples. There are important Thai cultural activities, such as Songkran when people sprinkle water on Buddharupa, monks and apprentices. After this, people will sprinkle the local elders. The temples also organize special activities, including Buddhist moral camps or sponsorship of monks to teach in schools and raise the knowledge level of the community. 


\subsection{The Problems with and Methods of Organizing Cultural Activities to Study Buddhist Teachings at Temples in Bangkok, Thailand}

The research discovered a number of problems with the current state of the organization of cultural activities to study Buddhist teachings at temples in Bangkok. The temples lack people with knowledge and ability in the organization of various activities. There is also no training to create such experts, due to a lack of cooperation from the community, government and private sector. It was found that the form of activities is not compatible with the people who attend and that there are no standards. There is no variety to the activities and no acceptance of modern culture. There were found to be a number of management problems, particularly a lack of publicity and a lack of budget. Announcements regarding activities do not reach all members of the communities and new techniques for publicity are not employed. Advertisement for the younger generation is particularly inadequate and the majority consensus among youths is that temple activities are for older members of society. Modern technology and techniques are ignored by the temples, as there are no individuals with the required knowledge to employ such innovations. There is no use of the media and there is no sponsorship by the government and private companies.

\subsection{A Model for the Organization of Cultural Activities to Study Buddhist Teachings at Temples in Bangkok, Thailand}

The researchers made a variety of observations on studying the problems with the current state of the organization of cultural activities to study Buddhist teachings at temples in Bangkok. People responsible for the organization of cultural activities must develop and train in the techniques and methods of organization. The development will give the organizers knowledge, ability and vision to create innovative activities in teams. The style and form of activities are not interesting to the local community, which can be remedied through development and cooperation. The activities must be fashionable and not repetitive. There must be a variety of activities for different ages and tastes. In order for this to be achieved, all members of society must be invited to contribute to the organization of the activities. The coordination and administration of budgets must be considered to push the activities towards fulfilling their objectives. The variety of publicity must be developed to include use of the internet, which will enable access by all members of the community. Development must include the development of sentiment among the local community to make people want to attend the activities, as well as seeking support from the government and private sector. Technology must be used as a medium to draw people to participate in the activities. It must also be incorporated within the activities to provide both real and abstract meaning to the events and increase the understanding and knowledge of the participants.

The model for the organization of cultural activities to study Buddhist teachings at temples in Bangkok used the following steps. The first is to plan the organizational operation of the activity to study Buddhist teachings and to designate people to be responsible for the area, buildings, budgets, activity style, publicity and technology. The second step is action. The implementation of the plans must be carried out exactly and must draw interest of people in the area to attend and participate in the activity. Creative analysis and problem solving skills must be employed to eradicate and counter any problems during the activity. The third step is evaluation. At the end of the activity there must be evaluation to determine whether the aims and objectives of the activity have been met. The satisfaction of the participants must also be determined, as well as the benefits of holding the activity.

There should be four sub-categories of activity within the event: a) activities to increase the knowledge of Buddhist teachings among children aged seven to twelve; b) activities to increase the knowledge of Buddhist teachings among young people aged thirteen to twenty-five; c) activities to increase the knowledge of Buddhist teachings among working adults aged twenty-six to sixty; d) activities to increase the knowledge of Buddhist teachings among elderly people over the age of sixty.

From the research workshop, it was concluded that there must be three important stages of the organization: a preliminary stage to consider the concepts of the activity, an intermediary stage for organizers to fully prepare and implement their own responsibilities in line with the aims and interests of the local community, and a final stage to evaluate the event and highlight areas of improvement for further activities.

\section{Discussion}

\subsection{The Historical Background of Temples and the Organization of Cultural Activities to Study Buddhist Teachings at Temples in Bangkok, Thailand}

In order to conduct this study, the researchers adopted the structural-functional theory of Sanya Sanyawiwat (2000, p. 25-54), which concerned the responsibilities of different social structures in the process of social integration. The theory concluded that social structures have deep and clear relationships or roles towards one 
another because these structures are the components of the society and are thus linked to form a larger composition. Each structure will have a specific role. If one of these structures is lacking or broken, it will be unable to perform its function, which will in turn cause other structures to disintegrate and become less effective, resulting in the breakdown of society. When investigating the background of temples and the organization of cultural activities to study Buddhist teachings at temples in Bangkok, the researchers examined the different components of the local communities in order to completely understand the full workings of the temples, the area and the activities that were organized.

\subsection{The Problems with and Methods of Organizing Cultural Activities to Study Buddhist Teachings at Temples in Bangkok, Thailand}

When examining the problems with organizing cultural activities to study Buddhist teachings at temples in Bangkok, the researchers considered the social conflict theory of Karl Marx. The theory holds that a social system must be derived from the cultural value of its customs, beliefs, religion and ideas. The important roots of economic systems are the social conditions of a society, including law, religion and philosophy. If these roots are not finely balanced and the system does not benefit every component, there will be social class conflict. This theory enabled the researchers to correctly locate and identify problems with organizing cultural activities to study Buddhist teachings at temples in Bangkok, which included staffing, publicity and use of technology.

The researchers also used the psychological concept of socialization. This is a concept concerning the continual processes of inheritance and dissemination by an individual in a society. The key to the process is the skill of parents and educators in teaching and training, particularly including explanation, speech, reading and sociability. This concept enabled the researchers to identify areas for developing the organization of cultural activities to study Buddhist teachings at temples in Bangkok.

\subsection{A Model for the Organization of Cultural Activities to Study Buddhist Teachings at Temples in Bangkok, Thailand}

The research results found that the organization of cultural activities to study Buddhist teachings at temples in Bangkok must use plan, action and evaluation. This is similar to the study of the philosophical foundations of administration and education by Somsak Kongtieng (1999, p. 1-3), which identified POSDCORB as the ideal method of administrative management. PODSCORB is an acronym that represents planning, organizing, staffing, directing, coordinating, reporting and budgeting.

Additionally, Watchara Kleinatorn (1987, p. 102-103) stated that culture and social environment are continually improved and developed to allow for integration. Each different culture is strengthened so that the behavior and conduct of the people within the society are accepted and people can coexist harmoniously and peacefully. In light of this, there are two paths for the development of a model for the organization of cultural activities to study Buddhist teachings at temples in Bangkok. The first path is the development of the organizers. This includes improving their organizational ability, vision and knowledge of modern methods, including the use of technology. This development corresponds to the work of Panatda Noppanawan (1989, p. 102-104), whose research of monastery institutions concluded that the knowledge of monks regarding Buddhist doctrine must be developed. The second path is the development of organization techniques, which is also consistent with Noppanawan's findings (1989), as well as the work of Prapasri Siha-ampai (1997, p. 4-6) in her study of social and cultural training.

By implementing the model outlined by the researchers and realizing the needs of all members of the local community, the temples can improve the organization of their cultural activities to teach Buddhist principles. If these improvements can be made then the local community and its knowledge of Buddhist morals will be strengthened, allowing these important cultural activities to continue for the benefit of future generations.

\section{References}

Kleinatorn, W. (1987). Early Sociology. Bangkok: Thai Wattana-Panich.

Kongtieng, S. (1999). The Foundations of Education Administration. Bangkok: Ramkamhaeng University.

Kosajarn, P. (2002). Study for Creating Sasanatayat. Bangkok: Chulalongkorn Publishers.

Kunaporn, P. (2008). Buddhadhamma: Natural Laws and Values for Life. New York: Suny Press.

Malatong, S. (1990). Education history of monks. Bangkok: Department of Religion.

Noppanawan, P. (1989). Study of the Communication Processes used by Thai Monastic Institutes for Publicizing Dharma. Bangkok: Chulalongkorn University. 
Pinitjan, S. (1994). Religious Words. Bangkok:Thai Wattana-Panich.

Sanyawiwat, S. (2000). Administration of Buddhist Concepts. Bangkok: Chulalongkorn Publishers.

Siha-ampai, P. (1997). Social and Cultural Training. Bangkok: Chulalongkorn University.

\section{Copyrights}

Copyright for this article is retained by the author(s), with first publication rights granted to the journal.

This is an open-access article distributed under the terms and conditions of the Creative Commons Attribution license (http://creativecommons.org/licenses/by/3.0/). 